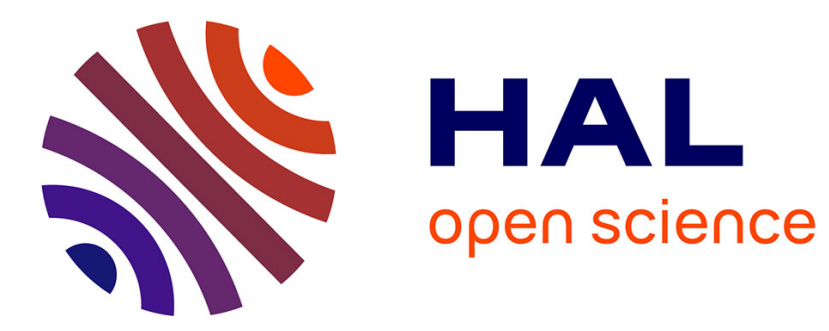

\title{
Equilibrium zinc isotope fractionation in Zn-bearing minerals from first-principles calculations
}

Manoj Ducher, Marc Blanchard, Etienne Balan

\section{To cite this version:}

Manoj Ducher, Marc Blanchard, Etienne Balan. Equilibrium zinc isotope fractionation in Znbearing minerals from first-principles calculations. Chemical Geology, 2016, 443, pp.87 - 96. 10.1016/j.chemgeo.2016.09.016 . hal-01376665

\section{HAL Id: hal-01376665 \\ https://hal.sorbonne-universite.fr/hal-01376665}

Submitted on 5 Oct 2016

HAL is a multi-disciplinary open access archive for the deposit and dissemination of scientific research documents, whether they are published or not. The documents may come from teaching and research institutions in France or abroad, or from public or private research centers.
L'archive ouverte pluridisciplinaire HAL, est destinée au dépôt et à la diffusion de documents scientifiques de niveau recherche, publiés ou non, émanant des établissements d'enseignement et de recherche français ou étrangers, des laboratoires publics ou privés. 


\title{
Equilibrium zinc isotope fractionation in Zn-bearing minerals from first-principles calculations
}

\author{
Manoj Ducher ${ }^{1, *}$, Marc Blanchard ${ }^{1}$, Etienne Balan ${ }^{1,}$
}

\begin{abstract}
Isotopic composition analysis contributes significantly to the investigation of the biogeochemical cycle of zinc with its economical, environmental and health implications. Interpretation of isotopic measurements is however hindered by the lack of a set of equilibrium isotopic fractionation factors between Zn-bearing minerals. In this study, equilibrium mass-dependent $\mathrm{Zn}$ isotope fractionation factors in Zn-bearing minerals are determined from first-principles calculations within the density functional theory (DFT) scheme. A wide range of minerals belonging to sulfide, carbonate, oxide, silicate, sulfate and arsenate mineral groups are modelled to account for the natural diversity of Zn crystal-chemical environment. Calculated reduced partition function ratios ( $\beta$-factors) span a range smaller than $2 \%$ at $22^{\circ} \mathrm{C}$. All studied secondary minerals (adamite, gahnite, gunningite, hemimorphite, hydrozincite, zincite) but zinc carbonate (smithsonite) are isotopically heavier than zinc sulfide minerals (sphalerite and wurtzite) from which they could form through supergene processes. Zinc-aluminium spinel and zinc silicate are the isotopically heaviest minerals. The investigation of the crystalchemical parameters at the origin of differences in isotopic properties shows an excellent linear correlation between $\ln \beta$ and $\mathrm{Zn}$ interatomic force constants. $\beta$-factors are also observed to increase when the $\mathrm{Zn}$-first neighbour bond lengths decrease and charges on atoms involved in the bonding increase and vice versa. These findings are in line with the observation of heavy isotope enrichment in systems having the largest bond strength.
\end{abstract}

Keywords: zinc isotope fractionation, ab initio, equilibrium fractionation, Zn mineral

\section{Introduction}

Anthropic activities affect global Zn cycle and cause major environmental issues. Globally the anthropic Zn reservoir $\left(4.9 \times 10^{5} \mathrm{Gg} \mathrm{Zn}\right)$ and flux are of the same order of magnitude as the natural ones (Rauch and Pacyna, 2009). About half of extracted $\mathrm{Zn}$ are discarded from anthropic reservoir to soils, which are the third largest reservoir of this element after Earth's mantle and crust (Rauch and Pacyna, 2009). Once in soils, $\mathrm{Zn}$ is either trapped or mobilised to other reservoirs like freshwater, oceans and atmosphere. Mechanisms such as Zn incorporation in minerals, precipitation, adsorption and dissolution control its mobility and would either attenuate or enhance $\mathrm{Zn}$ pollution. These processes are in turn controlled by environmental factors such as $\mathrm{pH}$, the presence of bio-organisms and crystalline phases (clay minerals, transition element oxides and Zn-bearing minerals) that change the speciation of Zn. Moreover, $\mathrm{Zn}$ is a vital dietary element (Frassinetti et al., 2006). Its deficiency as well as its excess are known to be related to several health issues. Therefore, the knowledge

\footnotetext{
* Corresponding author

Email address: manoj.ducher@impmc.upmc.fr (Manoj Ducher)

${ }^{1}$ Institut de Minéralogie, de Physique des Matériaux et de Cosmochimie (IMPMC), Sorbonne Universités, UPMC Univ Paris 06, CNRS UMR 7590, Muséum National d'Histoire Naturelle, IRD UMR 206, 4 place Jussieu, F-75005 Paris, France
}

of Zn speciation and so, its mobility and bioavailability, is of a great importance and is a major environmental challenge.

Speciation changes are known to induce isotopic fractionations. Thus, Zn isotope fractionation imposes itself as a relevant physical process that can be used to address these questions, and analytical techniques paved the way for precise Zn isotope measurements (Maréchal, 1998). Zn displays five stable isotopes with atomic masses 64,66 , $67,68,70$ and relative abundances of $48.6 \%, 27.9 \%, 4.1 \%$, $18.8 \%$ and $0.6 \%$ respectively. Zn isotope compositions are usually expressed as $\delta^{66} \mathrm{Zn}$ defined as the measured isotopic ratio in a sample with respect to JMC Lyon standard solution (Maréchal et al., 1999):

$$
\delta^{66} \mathrm{Zn}=\left[\frac{\left({ }^{66} \mathrm{Zn} /{ }^{64} \mathrm{Zn}\right)_{\text {sample }}}{\left({ }^{66} \mathrm{Zn} /{ }^{64} \mathrm{Zn}\right)_{\mathrm{JMC} \text { Lyon }}}-1\right] \times 1000
$$

Several studies measured Zn isotope compositions in both synthetic and natural materials. In the latter, the lowest $\delta^{66} \mathrm{Zn}$ value has been so far measured in lunar samples with $\delta^{66} \mathrm{Zn}=-11.4 \%$ (Kato et al., 2015) while the largest value has been found in primitive meteorites by Moynier et al. (2011a) with $\delta^{66} \mathrm{Zn}=7.35 \%$. In comparison, $\delta^{66} \mathrm{Zn}$ of terrestrial geological materials spread into a small range comprised between $-0.80 \%$ and $2.5 \%$ (Pichat et al., 2003; Mason et al., 2005; Wilkinson et al., 2005; 
Toutain et al., 2008; Chen et al., 2009; Moynier et al., 2009a; Pons et al., 2011; Gagnevin et al., 2012; Pašava et al., 2014; Little et al., 2014; Zhao et al., 2014) and the average $\delta^{66} \mathrm{Zn}$ of igneous rocks is $0.28 \pm 0.05 \%$ (Maréchal, 1998; Cloquet et al., 2006; Herzog et al., 2009; Paniello et al., 2012; Chen et al., 2013). Zn isotope composition have been widely used to trace environmental processes, to study spatial extension of metal pollution and to identify some attenuation mechanisms. As mining and smelting activities contribute to a large extent in $\mathrm{Zn}$ pollution, a number of works have measured isotopic compositions in regions impacted by industrial activities (Borrok et al., 2008, 2009; Balistrieri et al., 2008; Mattielli et al., 2009; Juillot et al., 2011; Yin et al., 2015). Other experimental studies investigated some of the mechanisms that potentially fractionate $\mathrm{Zn}$ isotopes. Biotic processes involving uptake of $\mathrm{Zn}$ by living-organisms (plant, diatoms) have been shown to induce isotopic fractionation. Gélabert et al. (2006) and John et al. (2007) have observed that marine diatoms surface is preferentially enriched in heavy isotopes $\left(\Delta^{66} \mathrm{Zn}_{\text {surface-solution }}=0.3 \pm 0.1 \%\right.$ where $\left.\Delta^{66} \mathrm{Zn}_{\text {surface-solution }}=\delta^{66} \mathrm{Zn}_{\text {surface }}-\delta^{66} \mathrm{Zn}_{\text {solution }}\right)$ while cell-internalised $\mathrm{Zn}$ is lighter $\left(\Delta^{66} \mathrm{Zn}_{\text {cell-solution }}=-0.2\right.$ to $-0.8 \%$ ). In plants, Weiss et al. (2005, 2007), Viers et al. (2007), Moynier et al. (2009b) and Aucour et al. (2011) have found roots to be enriched in heavy isotopes with respect to leaves and shoots. Studies by Pokrovsky et al. (2005), Balistrieri et al. (2008), Juillot et al. (2008), Bryan et al. (2015) and Veeramani et al. (2015) investigated isotopic fractionation induced by adsorption on oxides and hydroxides and have reported a preferential sorption of heavy isotopes on minerals surface. Guinoiseau et al. (2016) measured enrichment in heavy isotopes at phyllosilicates surface with $\Delta^{66} \mathrm{Zn}_{\text {adsorbed-solution }}$ ranging from $0.11 \%$ at low $\mathrm{pH}$ and low ionic strength to $0.49 \%$ at high $\mathrm{pH}$ and high ionic strength. The knowledge of equilibrium fractionation factors are necessary to investigate the underlying processes leading to natural variations of $\mathrm{Zn}$ isotope composition. In a theoretical DFT-based study, Fujii and Albarède (2012) explained through the calculation of equilibrium fractionation factors, the preferential heavy $\mathrm{Zn}$ isotopes enrichment in roots and lighter ones in leaves of plants. The differences in complexation environment of $\mathrm{Zn}$ in phosphates that are found in roots, and malates and citrates present in leaves, are likely to be at the origin of the observed isotopic fractionation. Other studies of Fujii et al. (2010), Fujii et al. (2011), Black et al. (2011) and Fujii et al. (2014) based on Zn molecular clusters, have provided equilibrium fractionation factors for $\mathrm{Zn}$ in various aqueous solutions.

In minerals, equilibrium isotopic fractionation factors of $\mathrm{Zn}$ remain unknown. The knowledge of these factors are essential for instance, to understand isotopic composition modifications induced by post-depositional fractionation processes in contaminated soils (Mason et al., 2005; Weiss et al., 2007; Juillot et al., 2011). In order to provide a consistent set of equilibrium mass-dependent iso- topic fractionation factors, a selection of Zn-bearing minerals from various mineral groups, covering a large range of Zn crystallographic environments, are studied from firstprinciples within density functional theory (DFT). Starting from $\mathrm{Zn}$ primary ore (sphalerite $\mathrm{ZnS}$ ) the oxidation and alteration products (secondary minerals) are mainly formed through supergene processes. Several crystalline phases containing $\mathrm{Zn}$ have been identified in contaminated soils. Commonly observed minerals include zinc carbonate minerals (smithsonite $\mathrm{ZnCO}_{3}$ and hydrozincite $\left.\mathrm{Zn}_{5}\left(\mathrm{CO}_{3}\right)_{2}(\mathrm{OH})_{6}\right)$ and zinc silicate minerals like hemimorphite $\left(\mathrm{Zn}_{4} \mathrm{Si}_{2} \mathrm{O}_{7}(\mathrm{OH})_{2} \cdot \mathrm{H}_{2} \mathrm{O}\right)$ (Boni et al., 2005; Balassone et al., 2008; Jacquat et al., 2008, 2009). In acid mine drainage systems and smelter-impacted soils, zinc-iron and zinc-aluminium spinels namely franklinite $\left(\mathrm{ZnFe}_{2} \mathrm{O}_{4}\right)$ and gahnite $\left(\mathrm{ZnAl}_{2} \mathrm{O}_{4}\right)$ are found as well as the zinc oxide zincite (ZnO) (Kucha et al., 1996; Hochella et al., 1999; Sobanska, 1999; Juillot et al., 2003; Jacquat et al., 2009; Juillot et al., 2011). Steger and Desjardins (1980) show that oxidation of sphalerite could result in the formation of hydrated zinc sulfate, which could be gunningite $\left(\mathrm{ZnSO}_{4} \cdot \mathrm{H}_{2} \mathrm{O}\right)$ (Jambor and Boyle, 1962). Rarely occurring zinc arsenate (adamite $\mathrm{Zn}_{2} \mathrm{AsO}_{4}(\mathrm{OH})$ ) can also be found. In all these minerals, $\mathrm{Zn}$ displays one oxidation state $(+2)$ but is found in various crystallographic environments and with a coordination number ranging from 4 to 6 . The calculation of equilibrium isotopic fractionation factors allows to identify some of the crystal-chemical parameters controlling these isotopic properties and provide a theoretical basis for the interpretation of isotopic measurements.

\section{Methods}

\subsection{Equilibrium isotopic fractionation factors}

The equilibrium isotopic fractionation factor $\alpha(a, b, Y)$ between two phases $a$ and $b$ of an element $Y$ is defined as the ratio of isotope ratios. Equivalently, it can also be written as the ratio of the reduced partition function ratios:

$$
\alpha(a, b, Y)=\frac{\beta(a, Y)}{\beta(b, Y)}
$$

where $\beta(a, Y)$ is the reduced partition function ratio between phase $a$ and a perfect gas of atoms $Y$ (Bigeleisen and Mayer, 1947). In solids, equilibrium mass-dependent isotopic fractionation mainly arises from the vibrational motions of atoms. As described thoroughly by Blanchard et al. (2017 in press), the reduced partition function ratio, also called " $\beta$-factor", can be determined by computing vibrational frequencies using a harmonic ap- 
proach (Bigeleisen and Mayer, 1947):

$$
\begin{gathered}
\beta(a, Y)=\left[\prod_{i=1}^{3 N_{a t}} \prod_{\{\boldsymbol{q}\}} \frac{\nu_{\boldsymbol{q}, i}}{\nu_{\boldsymbol{q}, i}^{\prime}} \frac{\exp \left(-h \nu_{\boldsymbol{q}, i} / 2 k_{\mathrm{B}} T\right)}{1-\exp \left(-\mathrm{h} \nu_{\boldsymbol{q}, i} / k_{\mathrm{B}} T\right)}\right. \\
\left.\frac{1-\exp \left(-h \nu_{\boldsymbol{q}, i}^{\prime} / k_{\mathrm{B}} T\right)}{\exp \left(-h \nu_{\boldsymbol{q}, i}^{\prime} / 2 k_{\mathrm{B}} T\right)}\right]^{1 /(N q N)}
\end{gathered}
$$

where $\nu_{\boldsymbol{q}, i}$ and $\nu_{\boldsymbol{q}, i}$ are the vibrational frequencies with wavevector $\boldsymbol{q}$ and branch index $i=1,3 N_{\text {at }}$ in two isotopologues. $N_{\text {at }}$ is the number of atoms in the crystal unit-cell with $N$ sites for the $Y$ atoms. $T$ is the temperature, $h$ the Planck constant and $k_{\mathrm{B}}$ the Boltzmann constant. The second product is performed on a sufficiently large grid of $N_{q} q$-vectors in the Brillouin zone. For phonon calculations at $\Gamma$ (centre of Brillouin zone), the three translational modes with $\nu_{\mathbf{0}, i}=0$ are not considered. Eq. 3 takes into account the "rule of the high-temperature product" also called "Redlich-Teller rule" (Bigeleisen and Mayer, 1947; Urey, 1947), which accounts for the fact that there should be no isotopic fractionation at the high-temperature limit.

In some cases, the determination of the whole vibrational spectrum is prevented by the large number of atoms (electrons) in the unit-cell. In such cases, the calculation along three orthogonal directions, of the harmonic restoring force constants $F_{i}$ that tend to pull back the studied atom in its equilibrium position allows computing an approximate $\beta$-factor (Bigeleisen and Mayer, 1947):

$$
\beta \simeq 1+\sum_{i=1}^{3 N_{a t}} \frac{u_{i}^{\prime 2}-u_{i}^{2}}{24}=1+\frac{\Delta m}{m^{\prime} m} \frac{\hbar^{2}}{24 k_{\mathrm{B}}^{2} T^{2}} \sum_{i=1}^{3} F_{i}
$$

where $u_{i}$ is the ratio $h \nu_{i} / k_{\mathrm{B}} T$. Eq 4 can be used in replacement of the full frequency calculation only if the ratio $h \nu / k_{\mathrm{B}} T$ is small $(\lesssim 2)$. This approximation has been used in several studies investigating isotopic fractionation (Moynier et al., 2011b; Kowalski and Jahn, 2011; Kowalski et al., 2013).

\subsection{Modelling approach}

In order to compute the reduced partition function ratios in the harmonic approximation according to Eq. 3, the complete vibrational spectrum is required for each mineral. Starting from experimentally determined structural models, the atomic positions and lattice parameters are relaxed within the DFT scheme as implemented in the Quantum ESPRESSO suite of codes based on plane-waves and pseudopotentials (Giannozzi et al., 2009). For each mineral, the dynamical matrix is calculated within density functional perturbation theory (DFPT or linear response theory) and then diagonalised for two different $\mathrm{Zn}$ atomic masses (64 and 66) in order to obtain the vibrational frequencies of the two isotopologues. For franklinite, the complete $a b$ initio vibrational spectrum is not calculated due to the large number of atoms in the unit-cell and Eq 4 is used instead. The force constants required in

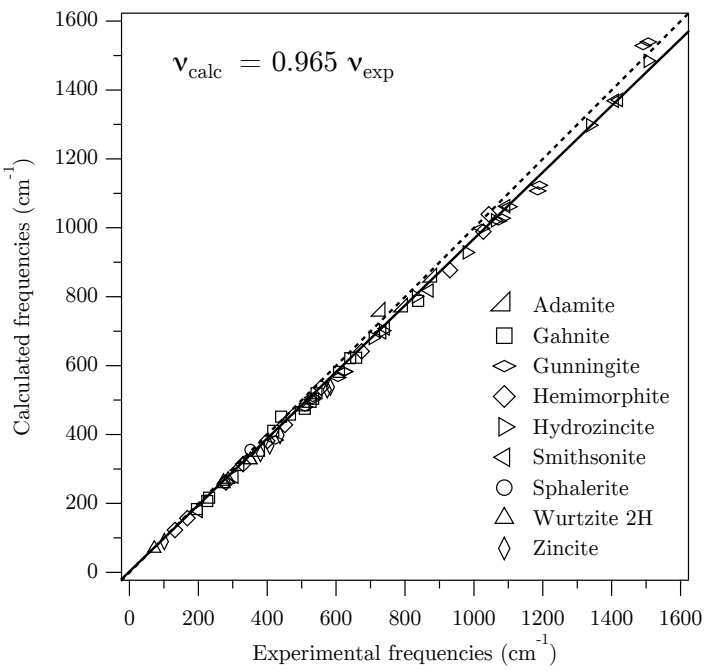

Figure 1: Calculated versus measured infrared and Raman frequencies of Zn-bearing minerals. Experimental frequencies of sphalerite, wurtzite $2 \mathrm{H}$ are from Brafman and Mitra (1968) and those of adamite, gahnite, gunningite, hydrozincite, smithsonite and zincite have been measured by Hill (1976), Chopelas and Hofmeister (1991), Rudolph et al. (1999), Frost et al. (2008a); Hales and Frost (2007), Frost et al. (2008a,b) and Damen et al. (1966) respectively. The dashed line corresponds to the 1:1 correlation. The solid line is the best linear fit through the origin in the $0-1600 \mathrm{~cm}^{-1}$ range.

this approach, can be obtained within the DFPT scheme where all inequivalent $\mathrm{Zn}$ atoms are displaced one after the other.

All calculations are performed with the Perdew-BurkeErnzerhof (PBE) parametrised generalised gradient approximation (GGA) functional (Perdew et al., 1996). Ultrasoft pseudopotentials from the GBRV library (Garrity et al., 2014) are used. The cut-off energies for wavefunctions (80 Ry) and charge-density (720 Ry) are determined such as the total energies are converged within $1 \mathrm{mRy} /$ atom. A regular grid in $k$-space according to Monkhorst and Pack (1976) scheme is used for Brillouin zone sampling. The size of the converged $k$-points grid for each mineral is indicated in Table 1 as well as the size of the $q$-points grid used for the calculation of the vibrational properties. For franklinite, calculations are spin-polarised to take into account the magnetic ordering. $\beta$-factor convergence with respect to $q$-points grid size has been tested for each mineral. Between the two most denser grids, the number of $q$-points is typically doubled and a difference of $\ln \beta$ of less than $0.1 \%$ is targeted. Structural relaxation is done until the residual forces on atoms are less than $10^{-4}$ $\mathrm{Ry} / \mathrm{au}$ and total energy difference between two consecutive SCF steps is less than $10^{-4} \mathrm{Ry}$.

\section{Results}

Calculated lattice parameters from DFT relaxed structures of the studied minerals compare well with their experimental counterparts. They are generally overestimated by around 1-2\%, which is the usual trend with 


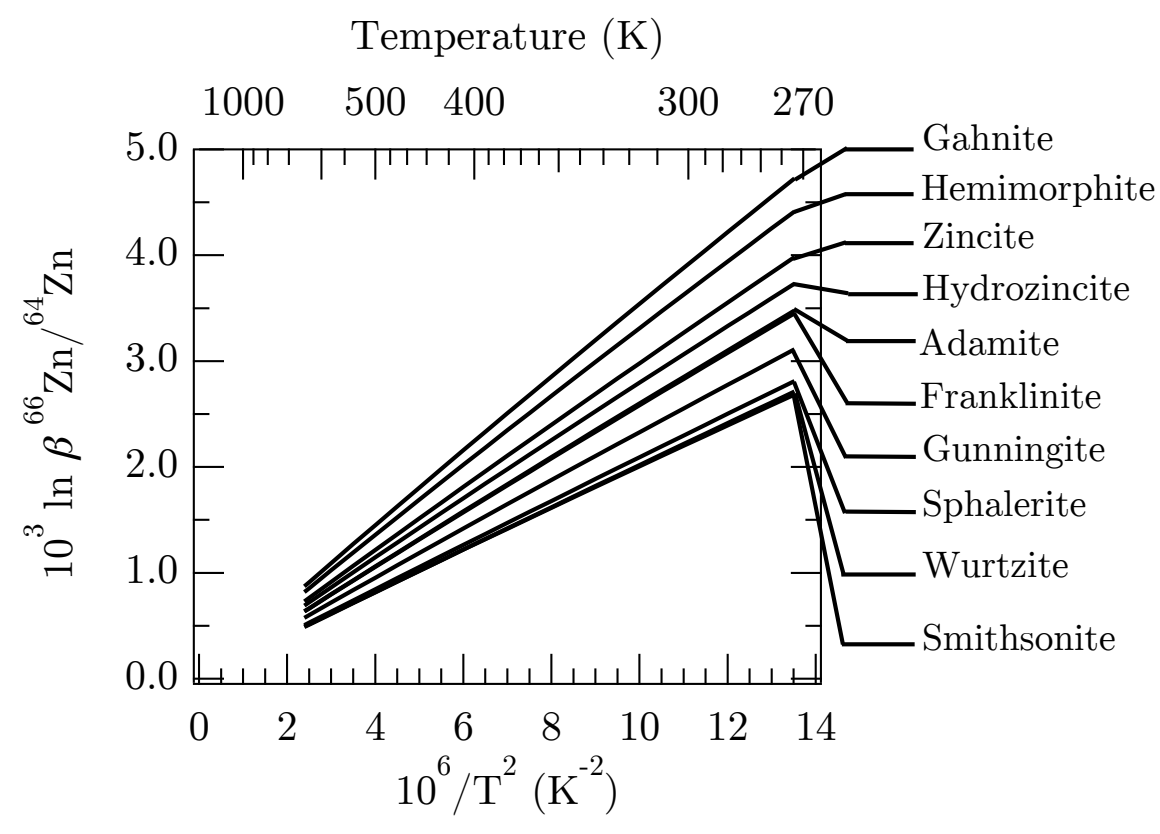

Figure 2: Temperature dependence of $\mathrm{Zn} \beta$-factors for $\mathrm{Zn}$-bearing minerals.

GGA PBE functional (Table 1). Only gunningite with its complex structure containing hydrogen bonds, displays a slightly larger distortion of the unit-cell with respect to the experimental values of Wildner and Giester (1991).

A good agreement is observed between calculated frequencies and experimental ones (Figure 1 and Table S1 of Supplementary Information) with a general underestimation of $\sim 4 \%$, commonly observed with GGA PBE functional (Méheut et al., 2009; Méheut and Schauble, 2014; Balan et al., 2014; He et al., 2014) related to the overestimation of the lattice parameters as shown by Favot and Dal Corso (1999). Equilibrium isotopic fractionation factors calculation is based on the knowledge of vibrational frequencies. Several studies rescaled the calculated harmonic frequencies to match the experimental ones (Schauble et al., 2006; Blanchard et al., 2009; Schauble, 2011; Widanagamage et al., 2014). This approach allows to obtain a better agreement between calculated and experimental frequencies, however, it may be hampered by either the lack of experimental vibrational spectra or an uncertain assignment of calculated and experimental vibrational modes. In those cases, the same scaling factor could be applied for all the studied systems but the calculated frequencies must have comparable deviations with respect to their experimental counterparts. Furthermore, Eq 3, which allows calculating the reduced partition function ratios, is only valid in the harmonic approximation. For these reasons, in our previous studies, we used the raw theoretical harmonic frequencies without any scaling (Méheut et al., 2007, 2009; Blanchard et al., 2010; Méheut and Schauble, 2014). In this study, we adopt the same approach by using unscaled vibrational frequencies.
Temperature dependence of the reduced partition function ratios of $\mathrm{Zn}$-bearing minerals are shown in figure 2 and parameters of empirical polynomial fits are given in Table 2. A quasi linear relation is observed between $\ln \beta$ and $1 / T^{2}$. At $22^{\circ} \mathrm{C}$, the whole set of $\ln \beta^{66} \mathrm{Zn} /{ }^{64} \mathrm{Zn}$ values are within a range of $2 \%$. $\beta$-factor of $\mathrm{Zn}$-bearing minerals are calculated according to $\mathrm{Eq} 3$ for all minerals except franklinite for which the full frequency calculation is not done due to the large number of electrons in the unitcell. From the force constant based approximate $\beta$-factor calculation for this mineral, the full frequency calculation $\beta$-factor is expected to be similar to hydrozincite $\mathrm{Zn} 2$ site $\beta$-factor for reasons explained in section 4.1. In figure 2 , the corrected franklinite $\beta$-factor is shown. Zinc carbonate mineral (smithsonite), zinc ore mineral sphalerite and its high-pressure polymorph (wurtzite), are amongst those having the lowest $\beta$-factors. All studied minerals except wurtzite and smithsonite are isotopically enriched in ${ }^{66} \mathrm{Zn}$ with respect to sphalerite. The highest values of $\beta$-factors can be found in the zinc-aluminium spinel (gahnite) and the zinc silicate (hemimorphite) where $\mathrm{Zn}$ atoms are fourfold coordinated with $\mathrm{O}$ atoms. In the ferric counterpart of gahnite (franklinite), values of $\ln \beta$ are lower by $1.1 \%$ at $22^{\circ} \mathrm{C}$. This value is even lower than that calculated for hydrozincite, which has three inequivalent $\mathrm{Zn}$ sites (1 tetra-coordinated and 2 hexa-coordinated sites). In both zincite and franklinite, Zn atoms are tetrahedrally coordinated to $\mathrm{O}$ atoms. 
Table 1: Modelling parameters, calculated and experimental lattice parameters of the investigated minerals (in $\AA$ ). (c), (h), (m) and (o) stand for cubic, hexagonal, monoclinic and orthorhombic crystal systems, respectively.

\begin{tabular}{|c|c|c|c|c|c|c|c|}
\hline & $\begin{array}{l}\text { structural } \\
\text { formula }\end{array}$ & sym & $\begin{array}{l}k \text {-points } \\
\text { grid }\end{array}$ & $\begin{array}{l}q \text {-points } \\
\text { grid }\end{array}$ & This study & Exp. & $\begin{array}{l}\text { Other theoretical } \\
\text { studies }\end{array}$ \\
\hline Sphalerite & $\mathrm{ZnS}$ & (c) & $3 \times 3 \times 3$ & $5 \times 5 \times 5$ & $a=5.444$ & $5.411^{a}$ & $5.449^{b}$ \\
\hline \multirow[t]{2}{*}{ Wurtzite $2 \mathrm{H}$} & $\mathrm{ZnS}$ & (h) & $4 \times 4 \times 3$ & $4 \times 4 \times 3$ & $a=3.842$ & $3.823^{a}$ & $3.755^{c}$ \\
\hline & & & & & $c=6.303$ & 6.261 & 6.168 \\
\hline \multirow[t]{2}{*}{ Wurtzite $4 \mathrm{H}$} & $\mathrm{ZnS}$ & $(\mathrm{h})$ & $4 \times 4 \times 2$ & $3 \times 3 \times 3$ & $a=3.844$ & $3.828^{d}$ & \\
\hline & & & & & $c=12.59$ & 12.52 & \\
\hline \multirow[t]{3}{*}{ Adamite } & $\mathrm{Zn}_{2} \mathrm{AsO}_{4}(\mathrm{OH})$ & $(\mathrm{o})$ & $2 \times 2 \times 2$ & $2 \times 2 \times 2$ & $a=8.491$ & $8.306^{e}$ & \\
\hline & & & & & $b=8.654$ & 8.524 & \\
\hline & & & & & $c=6.160$ & 6.043 & \\
\hline Franklinite & $\mathrm{ZnFe}_{2} \mathrm{O}_{4}$ & (c) & $1 \times 1 \times 1$ & $1 \mathrm{x} 1 \mathrm{x} 1$ & $a=8.505$ & $8.431^{f}$ & $8.453^{g}$ \\
\hline Gahnite & $\mathrm{ZnAl}_{2} \mathrm{O}_{4}$ & (c) & $1 \times 1 \times 1$ & $1 \mathrm{x} 1 \mathrm{x} 1$ & $a=8.183$ & $8.081^{h}$ & $8.231^{i}$ \\
\hline \multirow[t]{4}{*}{ Gunningite } & $\mathrm{ZnSO}_{4} \cdot \mathrm{H}_{2} \mathrm{O}$ & $(\mathrm{m})$ & $2 \times 2 \times 2$ & $2 \times 2 \times 2$ & $a=6.824$ & $6.925^{j}$ & \\
\hline & & & & & $b=7.923$ & 7.591 & \\
\hline & & & & & $c=7.776$ & 7.635 & \\
\hline & & & & & $\beta=117.3^{\circ}$ & $118.2^{\circ}$ & \\
\hline \multirow[t]{3}{*}{ Hemimorphite } & $\mathrm{Zn}_{4} \mathrm{Si}_{2} \mathrm{O}_{7}(\mathrm{OH})_{2} \cdot \mathrm{H}_{2} \mathrm{O}$ & (o) & $3 \times 3 \times 3$ & $2 \times 2 \times 3$ & $a=8.486$ & $8.367^{k}$ & \\
\hline & & & & & $b=10.80$ & 10.73 & \\
\hline & & & & & $c=5.255$ & 5.115 & \\
\hline \multirow[t]{4}{*}{ Hydrozincite } & $\mathrm{Zn}_{5}\left(\mathrm{CO}_{3}\right)_{2}(\mathrm{OH})_{6}$ & $(\mathrm{~m})$ & $1 \times 2 \times 2$ & $2 \times 2 \times 2$ & $a=13.73$ & $13.62^{l}$ & \\
\hline & & & & & $b=6.412$ & 6.30 & \\
\hline & & & & & $c=5.456$ & 5.42 & \\
\hline & & & & & $\beta=95.43^{\circ}$ & $95.83^{\circ}$ & \\
\hline \multirow[t]{2}{*}{ Smithsonite } & $\mathrm{ZnCO}_{3}$ & $(\mathrm{~h})$ & $2 \times 2 \times 1$ & $2 \times 2 \times 2$ & $a=4.714$ & $4.653^{m}$ & $4.72^{n}$ \\
\hline & & & & & $c=15.28$ & 15.03 & 15.22 \\
\hline \multirow[t]{2}{*}{ Zincite } & $\mathrm{ZnO}$ & $(\mathrm{h})$ & $3 \times 3 \times 2$ & $5 \times 5 \times 5$ & $a=3.278$ & $3.250^{\circ}$ & $3.198^{c}$ \\
\hline & & & & & $c=5.307$ & 5.207 & 5.167 \\
\hline
\end{tabular}

${ }^{a}$ Skinner (1961)

${ }^{b}$ Blanchard et al. (2009)

${ }^{c}$ Bachmann et al. (2012)

${ }^{d}$ Chao and Gault (1998)

${ }^{e}$ Hill (1976)

${ }^{f}$ Braestrup et al. (2008)

${ }^{g}$ Andersson and Stanek (2013)

${ }^{h}$ Mitchell et al. (1996)

${ }^{i}$ Yousaf et al. (2012)

${ }^{j}$ Wildner and Giester (1991)

${ }^{k}$ Libowitzky and Rossman (1997)

${ }^{l}$ Ghose (1964)

${ }^{m}$ Graf (1961)

${ }^{n}$ Bouibes et al. (2013)

${ }^{o}$ Kisi and Elcombe (1989) 
Table 2: Polynomial fits of type $a x^{2}+b x$ of $10^{3} \ln \beta$, with $x=10^{6} / T^{2}$ $\left(T\right.$ in $\mathrm{K}$ ) for ${ }^{66} \mathrm{Zn} /{ }^{64} \mathrm{Zn}$ isotope ratio. $\mathrm{Zn} 1, \mathrm{Zn} 2, \mathrm{Zn} 3$ stand for each inequivalent $\mathrm{Zn}$ crystallographic site, when applicable.

\begin{tabular}{|c|c|c|}
\hline & $a\left(\mathrm{~K}^{4}\right)$ & $b\left(\mathrm{~K}^{2}\right)$ \\
\hline Adamite & $-8.49 \times 10^{-4}$ & 0.2687 \\
\hline $\mathrm{Zn} 1$ & $-8.73 \times 10^{-4}$ & 0.2574 \\
\hline $\mathrm{Zn} 2$ & $-8.24 \times 10^{-4}$ & 0.2801 \\
\hline Franklinite & $-9.37 \times 10^{-4}$ & 0.2679 \\
\hline Gahnite & $-1.39 \times 10^{-3}$ & 0.3683 \\
\hline Gunningite & $-8.87 \times 10^{-4}$ & 0.2420 \\
\hline Hemimorphite & $-1.41 \times 10^{-3}$ & 0.3455 \\
\hline Hydrozincite & $-1.12 \times 10^{-3}$ & 0.2911 \\
\hline $\mathrm{Zn} 1$ & $-7.71 \times 10^{-4}$ & 0.2525 \\
\hline $\mathrm{Zn} 2$ & $-9.37 \times 10^{-4}$ & 0.2679 \\
\hline Zn3 & $-1.48 \times 10^{-3}$ & 0.3336 \\
\hline Smithsonite & $-6.49 \times 10^{-4}$ & 0.2073 \\
\hline Sphalerite & $-3.82 \times 10^{-4}$ & 0.2132 \\
\hline Wurtzite $^{a}$ & $-3.73 \times 10^{-4}$ & 0.2058 \\
\hline Zincite & $-9.92 \times 10^{-4}$ & 0.3081 \\
\hline
\end{tabular}

${ }^{a}$ Reported wurtzite $\beta$-factor value is for the $2 \mathrm{H}$ polytype. $4 \mathrm{H}$ polytype $\ln \beta$ only differs by $0.02 \%$ at $22^{\circ} \mathrm{C}$, i.e. at the limit of the experimental resolution.

\section{Discussion}

\subsection{Crystal-chemical parameters controlling $\mathrm{Zn}$ isotope fractionation in minerals}

Parameters controlling $\mathrm{Zn}$ isotope fractionation between minerals (Figure 2) are discussed here. General rules governing isotopic fractionation predict that stiff bonds will tend to concentrate heavy isotopes (Schauble, 2004). The stiffness of the interatomic bonds can be evaluated by the interatomic force constants. The dependence of $\beta$-factors over $\mathrm{Zn}$ interatomic force constant $F$ is illustrated by the approximate Eq 4. As the second term on the right hand side of Eq 4 is very small and vanishes when the temperature increases, $\ln \beta$ is proportional to $F$, with $F$ being the sum of interatomic force constants along three orthogonal directions $\left(F=\sum_{i=1}^{3} F_{i}\right)$. In figure $3, \ln \beta{ }^{66} \mathrm{Zn} /{ }^{64} \mathrm{Zn}$ at $22^{\circ} \mathrm{C}$ are plotted as a function of $F$ for all inequivalent $\mathrm{Zn}$ crystallographic site in the studied minerals (solid line). $\ln \beta$ increases proportionally with interatomic force constant with an excellent linear correlation between them (Pearson's $r=0.999$ ). This relationship reflects the strong dependence of isotopic fractionation with interatomic force constants and thus, the bond strength. In figure $3, \ln \beta$ calculated using Eq 4 are also shown in order to compare the full frequency calculation to the approximate one (dashed line). In this study, the approximation systematically overestimates $\beta$-factors with respect to the full calculation with an average value of $\ln \beta$ difference between the two methods of $0.12 \%$ and a standard deviation of $0.07 \%$ at $22^{\circ} \mathrm{C}$. At small $F$ values, the force constant derived $\ln \beta$ is very close to the $\ln \beta$ derived from full frequency calculation while it deviates at high $F$. Small values of $F$ correspond to long bonds and vice-versa. $\beta$-factor calculation using Eq 4 is valid only when $h \nu$ is small with respect to $k_{\mathrm{B}} T$. For a given temperature, larger bond lengths lead to smaller vibrational frequencies and the approximation holds while shorter bond lengths result in larger vibrational frequencies giving rise to the observed deviation. In franklinite, due to the presence of iron atoms and the large number of electrons, the $\beta$-factor is calculated according to $\mathrm{Eq} \mathrm{4}$, based on the $\mathrm{Zn}$ interatomic force constants. Zn site in this mineral has a similar interatomic force constant as hydrozincite Zn2 (Figure 3) and thus, the full frequency calculation is expected to give also a $\ln \beta$ similar to hydrozincite $\mathrm{Zn} 2\left(2.95 \%\right.$ at $\left.22^{\circ} \mathrm{C}\right)$.

Some studies (Young et al., 2009, 2015; Macris et al., 2015) have suggested that interatomic force constants derived from empirical interionic potential such as BornMayer or Born-Landé potentials could be used to estimate equilibrium fractionation factors and understand crystal-chemical parameters controlling isotopic fractionation. These analytical expressions of $F$ show that the bond strength is mainly controlled by the charge of the two atoms involved in the bonding and the distance between them. In order to evaluate the impact of bond lengths on $\mathrm{Zn}$ isotope fractionation, $\ln \beta^{66} \mathrm{Zn} /{ }^{64} \mathrm{Zn}$ at $22^{\circ} \mathrm{C}$ are reported as a function of average $\mathrm{Zn}-\mathrm{O}$ bond lengths in figure 4 . The relation between fractionation factors and bond lengths were investigated by Schauble (2011) for Mg isotopes, by Kowalski and Jahn (2011); Kowalski et al. (2013) for Li and B isotopes and by Méheut and Schauble (2014) for $\mathrm{Si}$ isotope fractionation. An increase in fractionation factors is generally observed with the decrease of bond lengths. In line with these observations, figures 3 and 4 show that gahnite, hemimorphite and zincite are amongst the minerals having the largest $\beta$-factors and interatomic force constants, smallest bond lengths and are also those where $\mathrm{Zn}$ is tetrahedrally coordinated. Apart from sphalerite and wurtzite, smithsonite and gunningite have the lowest $\beta$-factors, interatomic force constants, largest bond lengths. In these minerals, $\mathrm{Zn}$ is found in octahedral sites. In between these two groups of minerals, there are adamite in which Zn has two coordination numbers (5 and 6), franklinite in which Zn sites have tetrahedral symmetry and hydrozincite in which $\mathrm{Zn}$ is found in both tetrahedral and octahedral sites. Overall, a general decrease of $\ln \beta^{66} \mathrm{Zn} /{ }^{64} \mathrm{Zn}$ when the bond length and coordination number increase can be seen, which is in agreement with the general rule of short bonds concentrating heavy isotopes (Schauble, 2004). However, unlike the correlation between $\ln \beta$ and $F$, there is not such a clear relationship between $\ln \beta$ and average bond lengths.

For Zn sulfide minerals, $\ln \beta$ and $F$ are correlated in the same way as for the all other minerals. Sphalerite and wurtzite with average Zn-S bond lengths of $2.36 \AA$ are out of the general trend of figure 4 because of differing chemical properties of $\mathrm{Zn}-\mathrm{S}$ bond with respect to $\mathrm{Zn}-\mathrm{O}$ bond. These two minerals display very close $\beta$-factor values with a $\ln \beta$ difference of $0.08 \%$ at $22^{\circ} \mathrm{C}$, which is in agreement with the 


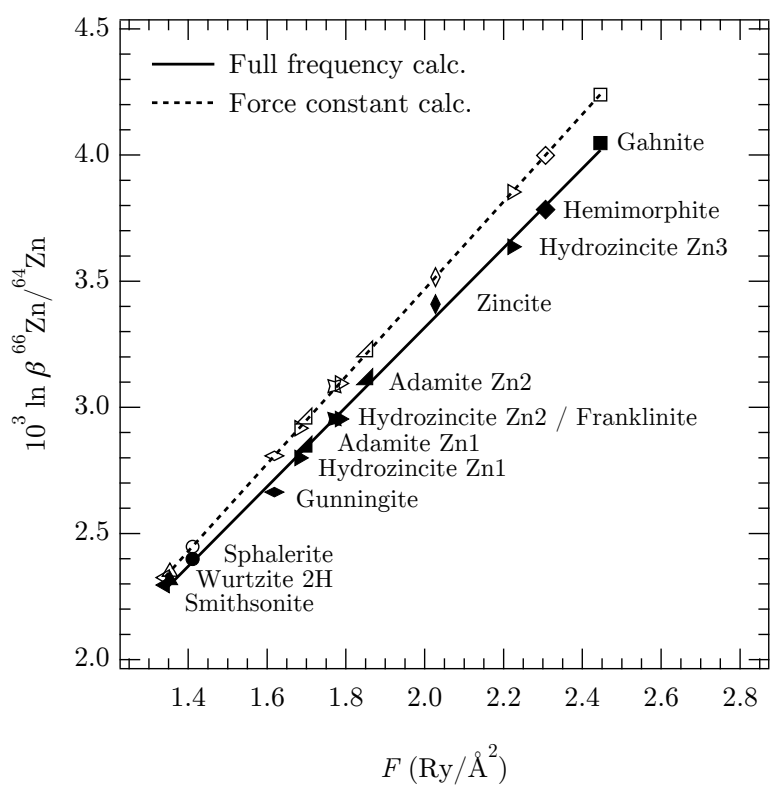

Figure 3: $\ln \beta^{66} \mathrm{Zn} /{ }^{64} \mathrm{Zn}$ at $22^{\circ} \mathrm{C}$ as a function of ab initio interatomic force constants for each site in the studied minerals. Closed and open symbols refer to $\beta$-factors calculated according to Eq 3 and Eq 4 respectively. Solid and dashed lines are the corresponding linear fits: $10^{3} \ln \beta^{66} \mathrm{Zn} /{ }^{64} \mathrm{Zn}=1.5767 F+0.1640$ for the full frequency calculation and $10^{3} \ln \beta^{66} \mathrm{Zn} /{ }^{64} \mathrm{Zn}=1.7314 F+0.0067$ for the force constant based calculations. The full frequency calculation is not performed for franklinite. However, as hydrozincite $\mathrm{Zn} 2$ and franklinite display similar force constants, franklinite will have similar $\ln \beta$ as hydrozincite $\mathrm{Zn} 2$ if the full frequency calculation was done.

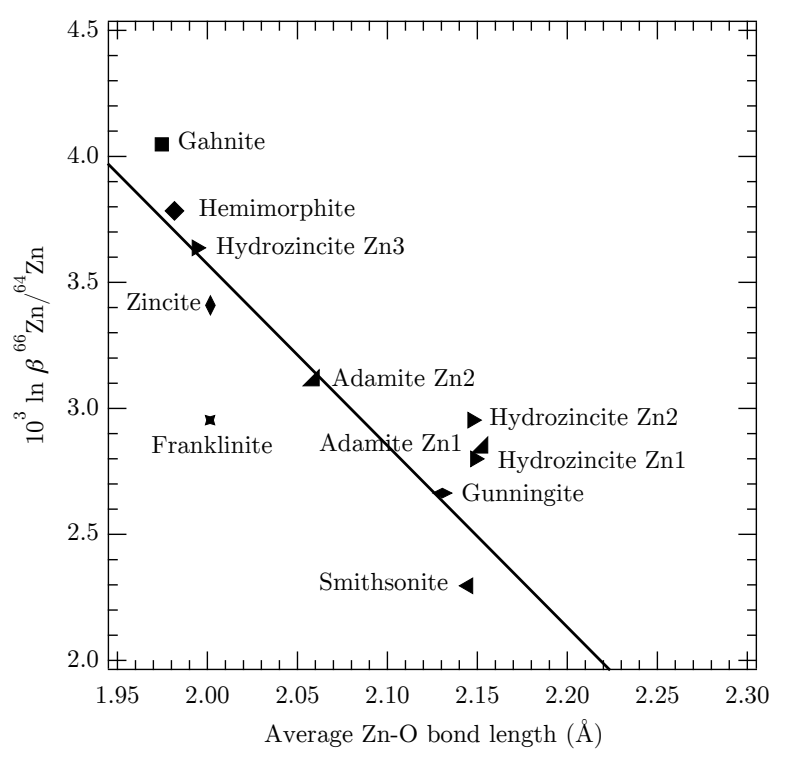

Figure 4: $\beta$-factors at $22^{\circ} \mathrm{C}$ as a function of average $\mathrm{Zn}-\mathrm{O}$ bond lengths for each $\mathrm{Zn}$ site or mineral. Solid black line is a guideline emphasizing the decrease of $\ln \beta$ with the increase of bond lengths. "very small fractionation" found by Schauble (2003). The same study reported a calculated value of $\ln \beta^{68} \mathrm{Zn} /{ }^{66} \mathrm{Zn}$ in zincite larger by $\sim 1 \%$ with respect to sphalerite at room temperature, which is consistent with our calculations where zincite is found $0.95 \%$ heavier than sphalerite at $22^{\circ} \mathrm{C}$ for these isotopes.

Smithsonite, where Zn atoms are octahedrally coordinated, has a $\beta$-factor value lower than sphalerite by $0.1 \%$ meaning that at equilibrium, it would be slightly enriched in light $\mathrm{Zn}$ isotopes with respect to coexisting sphalerite. In the meanwhile, zinc hydroxy-carbonate hydrozincite, which belongs to the same mineral group as smithsonite, displays a $\ln \beta$ of $3.20 \%$ that is $0.90 \%$ larger than smithsonite and consistently, its average $\mathrm{Zn}-\mathrm{O}$ bond strength is larger than in smithsonite by $0.6 \mathrm{Ry} / \AA^{2}$ and average $\mathrm{Zn}-\mathrm{O}$ bond length is smaller by $0.06 \AA$. An in-depth examination of site specific $\beta$-factors and bond lengths (Figure 4 ) shows that $\mathrm{Zn}$ in smithsonite has a smaller $\beta$-factor than $\mathrm{Zn}$ sitting in Zn1 and Zn2 octahedral symmetry sites in hydrozincite by $0.50 \%$ and $0.65 \%$ respectively, even if $\mathrm{Zn}-\mathrm{O}$ bond lengths are comparable. The investigation of the firstcoordination shell of $\mathrm{Zn}$ atoms points out electronic differences in the bonding environment, which in turn explain contrasting isotopic properties between $\mathrm{Zn}$ site in smithsonite and Zn1 and Zn2 sites in hydrozincite. As shown in figure 5, in smithsonite, all the six first-neighbours of a $\mathrm{Zn}$ atom are $\mathrm{O}$ atoms, while around $\mathrm{Zn}$ in $\mathrm{Zn} 1$ and $\mathrm{Zn} 2$ sites in hydrozincite there are four hydroxyl groups amongst the six first-neighbours. In the polar covalent $\mathrm{O}-\mathrm{H}$ bond, $\mathrm{O}$ atom gains a partial negative charge due to charge transfer from less electronegative $\mathrm{H}$ atom. Such an effect is absent in smithsonite and present in hydrozincite. In order to support this observation, we performed Löwdin charge calculation. The average charge on $\mathrm{O}$ atoms bonded to $\mathrm{Zn}$ is $2.4 \%$ smaller in smithsonite than in hydrozincite (for Zn1 and Zn2 sites). Thus, Zn-first neighbour bonds are weaker in smithsonite than in hydrozincite resulting in lower interatomic force constants and lower $\beta$-factors in smithsonite with respect to hydrozincite.

In adamite, Zn2 site has a trigonal bipyramidal symmetry formed by four $\mathrm{O}$ atoms and one $\mathrm{OH}$ group. As a result of this bonding environment, $\ln \beta$ is equal to $3.11 \%$ that is an intermediate value between minerals where $\mathrm{Zn}$ is tetrahedrally and octahedrally coordinated. The other site (Zn1) has an octahedral symmetry, with a corresponding $\ln \beta$ of $2.84 \%$ that is comparable to values calculated for $\mathrm{Zn} 1$ and $\mathrm{Zn} 2$ sites in hydrozincite.

In the modelling of franklinite, the normal spinel structure is considered, which is both the experimental and DFT ground-state structure (Braestrup et al., 2008; Andersson and Stanek, 2013). Zn atoms occupy the tetrahedral and $\mathrm{Fe}$ atoms the octahedral sites. In figure 3, franklinite appears to have lower values of $F$ and $\ln \beta$ than expected for a mineral in which $\mathrm{Zn}$ is tetrahedrally coordinated. In figure 4, franklinite does not appear to be in the general trend. Franklinite $\beta$-factor is below the 

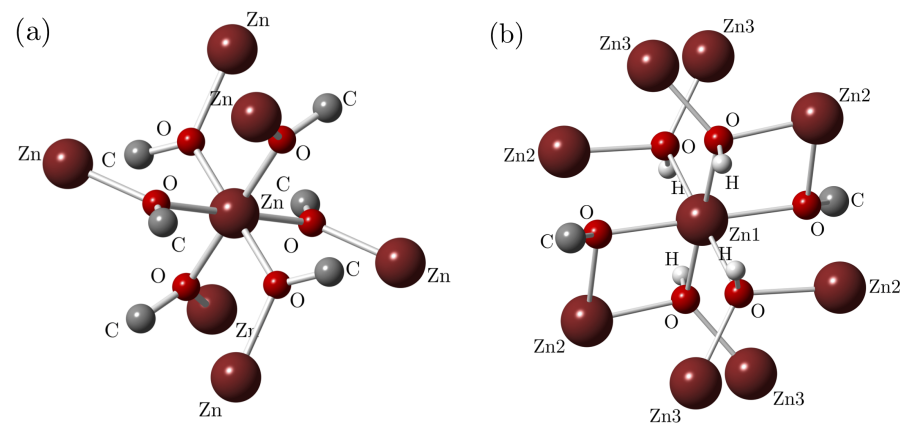

Figure 5: Ball and stick representation of octahedrally coordinated Zn environments in (a) smithsonite and (b) hydrozincite. calculated value for zincite (Figures 2, 3 and 4), although bond lengths and local environment around $\mathrm{Zn}$ atoms in both minerals are very similar, with $\mathrm{Zn}$ being coordinated to four $\mathrm{O}$ atoms. Results shown in figures 2, 3 and 4 for franklinite assumes a spin ordering as in model 1 shown in figure 6 but the antiferromagnetic ground-state can be obtained through various spin orderings (Cheng, 2008). The effect of magnetic ordering on $\beta$-factor is investigated by considering a second model (model 2) as shown in figure 6 . Both models are found to give a similar lattice parameter and similar Zn-O bond lengths. Model 1 is however lower in energy by $230 \mathrm{meV}$ with respect to model 2 and has a bandgap of $0.3 \mathrm{eV}$ while in the latter, it is $0.1 \mathrm{eV}$. Between these two models, a negligible change in $\ln \beta$ of less than $0.001 \%$ is observed. Consequently, franklinite $\beta$-factor remains doubtlessly lower than the zincite one, meaning that at equilibrium franklinite will be isotopically lighter than zincite. The first neighbour oxygen shells around $\mathrm{Zn}$ are identical in both minerals while the nature of the second neighbours is different, i.e. second neighbours are Fe atoms in franklinite and $\mathrm{Zn}$ atoms in zincite. In order to investigate the effect of second neighbours on the $\beta$-factor, a new model is made from relaxed franklinite, where all $\mathrm{Fe}$ atoms are replaced by $\mathrm{Al}$ atoms. The resulting fictitious mineral is chemically identical to gahnite $\left(\mathrm{ZnAl}_{2} \mathrm{O}_{4}\right)$ but structurally similar to franklinite. Then, without any relaxation, the restoring force constants acting on $\mathrm{Zn}$ are calculated through DFPT and $\beta$-factor is computed using Eq 4. At $22^{\circ} \mathrm{C}$, $\ln \beta$ has now increased from $2.95 \%$ to $3.64 \%$ that is closer to the expected value for tetrahedrally coordinated $\mathrm{Zn}$. The total charge on $\mathrm{O}$ atoms is calculated to be $3.8 \%$ lower in franklinite than in the fictitious mineral. The calculated total charge difference is the consequence of a charge transfer from $\mathrm{O}$ to $\mathrm{Fe}$ atoms that disappears when $\mathrm{Al}$ for $\mathrm{Fe}$ substitutions are made. In the optimised gahnite, $\mathrm{Zn}-\mathrm{O}$ bonds are the shortest and the average charge on $\mathrm{O}$ atoms is the highest amongst all investigated minerals. As a consequence, gahnite has the largest $\beta$-factor. Therefore $\mathrm{Zn}$ isotope fractionation in spinel minerals cannot be considered as a purely local property but is also a function of the medium-range environment of $\mathrm{Zn}$.

\subsection{Comparison between theoretical and experimental fractionation}

Only very few works exist in which $\mathrm{Zn}$ isotope fractionation has been measured in controlled experiments involving Zn-bearing minerals. Veeramani et al. (2015) studied $\mathrm{Zn}$ isotope fractionation between aqueous solutions and minerals such as sphalerite, hydrozincite and hopeite, which is a $\mathrm{Zn}$ phosphate. Sphalerite and hydrozincite were precipitated from $\mathrm{ZnSO}_{4}$ and $\mathrm{ZnCl}_{2}$ solutions respectively, to which $\mathrm{Na}_{2} \mathrm{~S}_{2}$ and $\mathrm{NaHCO}_{3}$ with varying concentration, were added in batch experiments, respectively. According to a Rayleigh fractionation model, sphalerite and hydrozincite were found to be isotopically lighter and heavier than initial solutions at room temperature,
Figure 6: Models of magnetic ordering used in this study for franklinite. Positions of Fe atoms are projected on the (100) plane and the numbers denote the relative distance from the plane to the position of unprojected Fe atoms. $\beta$-factors presented in Figs. 2, 3 and 4 are calculated assuming spin model 1. 
with $\varepsilon=-0.30 \%$ and $\varepsilon=+0.18 \%$ respectively. $\varepsilon$ is defined as:

$$
\varepsilon=\left(\frac{R_{\text {product }}}{R_{\text {reactant }}}-1\right) \times 1000
$$

where $\mathrm{R}$ is the isotopic ratio. A quantitative comparison of mineral-solution $\mathrm{Zn}$ isotope fractionation between experimental and theoretical studies requires several fulfilments: 1) a precise knowledge of Zn speciation in precipitated and dissolved phases, 2) the isotopic analysis of all reaction products, 3) and a reliable and consistent modelling of isotopic properties of both the solid and dissolved phases. In those experiments, the evolution of $\mathrm{Zn}$ speciation in the two different solutions is unknown and is required to deduce the relative enrichment between the two minerals. Indeed, during sphalerite precipitation, the $\mathrm{pH}$ varies from 3.87 to 11.45 , which would likely modify the speciation of aqueous $\mathrm{Zn}$. For the initial $\mathrm{ZnSO}_{4}$ solution, a geochemical calculation at $22^{\circ} \mathrm{C}, \mathrm{pH} 4$ and in equilibrium with atmospheric $\mathrm{CO}_{2}$ using PHREEQC (Parkhurst and Appelo, 1999) and WATEQ4F database (Ball and Nordstrom, 1991) indicates $70 \mathrm{~mol} \%$ and $29 \mathrm{~mol} \%$ of $\mathrm{Zn}$ in $\mathrm{Zn}_{(\mathrm{aq})}^{2+}$ and $\mathrm{ZnSO}_{4(\mathrm{aq})}$ forms respectively. The calculation for the initial $\mathrm{ZnCl}_{2}$ solution results in almost $98 \mathrm{~mol} \%$ of $\mathrm{Zn}$ in $\mathrm{Zn}_{(\mathrm{aq})}^{2+}$. $\mathrm{Zn}_{(\mathrm{aq})}^{2+}$ is commonly believed to be present as a hexaaquo complex $\left(\mathrm{Zn}\left(\mathrm{H}_{2} \mathrm{O}\right)_{6}^{2+}\right)$. $\mathrm{ZnSO}_{4(\mathrm{aq})}$ has been modelled by Black et al. (2011) as both inner and outersphere complexes and associated $\beta$-factors have been calculated. Rudolph et al. (1999) through Raman spectra measurements have shown that at low temperature and low $\mathrm{ZnSO}_{4}$ concentrations $\left(0.034 \mathrm{~mol} \mathrm{~kg}{ }^{-1}\right)$ the formation of a $1: 1$ contact ion pair $\left(\mathrm{Zn}^{2+} \mathrm{OSO}_{3}^{2-}\right)$ is unlikely. Furthermore, in experiments, the outer-sphere complex is undistinguishable in vibrational spectroscopy investigations from the bulk phase sulfate (Rudolph et al., 1999). As a consequence of these observations, we assume that the fractionation measured in Veeramani et al. (2015) experiments could be roughly approximated to represent isotopic fractionation between minerals and $\mathrm{Zn}\left(\mathrm{H}_{2} \mathrm{O}\right)_{6}^{2+}$ complex. The value $\varepsilon=-0.30 \%$ (respectively $\varepsilon=+0.18 \%$ ) would represent thus an average fractionation factor between sphalerite (respectively hydrozincite) and $\mathrm{Zn}$ hexaaquo complex.

In order to calculate the $\beta$-factor of $\mathrm{Zn}\left(\mathrm{H}_{2} \mathrm{O}\right)_{6}^{2+}$ complex using the same numerical methods as those used for Zn-bearing minerals, a large cubic cell of $20 \AA$ size is made and Martyna-Tuckerman correction (Martyna and Tuckerman, 1999) is enabled to avoid interaction of the charged $\mathrm{Zn}$ aqueous complex with its periodic images. $\mathrm{Zn}-\mathrm{O}$ bond lengths and vibrational frequencies of this complex are given in Table $\mathrm{S} 2$ and S3 of Supplementary Information. $\ln \beta^{66} \mathrm{Zn} /{ }^{64} \mathrm{Zn}$ at $22^{\circ} \mathrm{C}$ for $\mathrm{Zn}\left(\mathrm{H}_{2} \mathrm{O}\right)_{6}^{2+}$ is calculated to be $3.03 \%$. This value calculated with plane-wave basis set is in good agreement with Black et al. (2011) value of $3.11 \%$, which is calculated with B3LYP functionals and the largest localised basis set of the study (aug-cc- $p V D Z)$ at $22^{\circ} \mathrm{C}$. Sphalerite and hydrozincite $\ln \beta^{66} \mathrm{Zn} /{ }^{64} \mathrm{Zn}$ val-

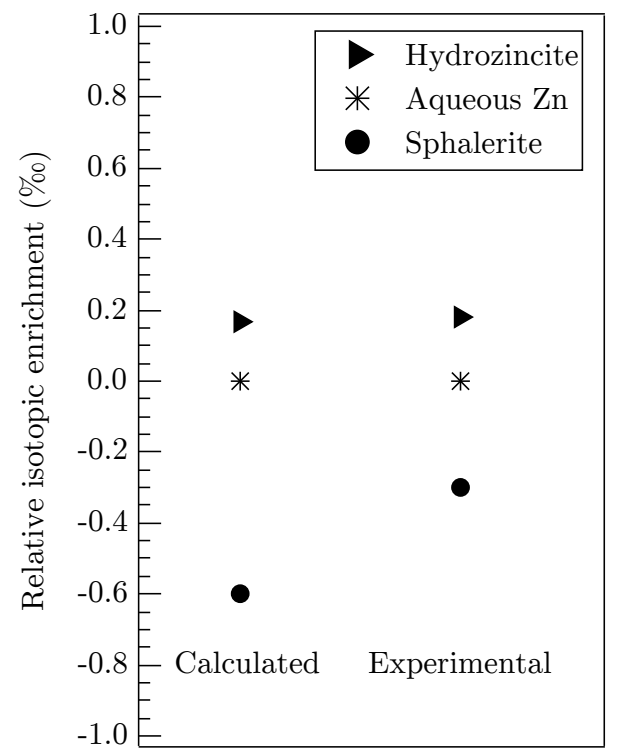

Figure 7: Relative isotopic enrichment of minerals relative to aqueous $\mathrm{Zn}$ at $22^{\circ} \mathrm{C}$. Aqueous $\mathrm{Zn}$ is modelled as $\mathrm{Zn}\left(\mathrm{H}_{2} \mathrm{O}\right)_{6}^{2+}$ complex. Calculated values are compared with experimental ones from Veeramani et al. (2015) study.

ues at $22^{\circ} \mathrm{C}$ are $2.40 \%$ and $3.19 \%$. Thus, equilibrium fractionation factors predict sphalerite and hydrozincite to be enriched in light and heavy isotopes with respect to aqueous $\mathrm{Zn}$, respectively (Figure 7 ). $\ln \beta$ differences between mineral and solution, which are $-0.63 \%$ for sphaleritesolution and $+0.17 \%$ for hydrozincite-solution, are consistent with the experimental values, which are $-0.3 \%$ and $+0.18 \%$ respectively. It should be noted that with increasing $\mathrm{NaHCO}_{3}$ concentration in $\mathrm{ZnCl}_{2}$ solution during hydrozincite precipitation, the formation of $\mathrm{Zn}$ carbonate complexes could be expected. These complexes display $\beta$-factor values higher than $\mathrm{Zn}$ hexaaquo complex one according to Fujii et al. (2014). As a consequence, including such complexes in Zn speciation modelling in hydrozincite precipitation experiment would result in the mineral being either less enriched in heavy isotopes than experimentally measured or even, ligther than the solution, which would be in contradiction with the experiment. In the same way, the addition of $\mathrm{Na}_{2} \mathrm{~S}_{2}$ in $\mathrm{ZnSO}_{4}$ solution during sphalerite precipitation would lead to the formation of $\mathrm{Zn}$ hydrogenosulfides complexes. These complexes display $\beta$-factors lower than $\mathrm{Zn}$ hexaaquo complex one. The consideration of these complexes in solution would result in a lower aqueous $\mathrm{Zn} \beta$-factor value than $3.03 \%$ calculated for $\mathrm{Zn}$ hexaaquo complex. $\ln \beta$ difference between sphalerite and solution could then decrease and potentially tend towards the experimental value of $\varepsilon=-0.3 \%$ (Figure 7 ). 


\subsection{Geochemical implications for natural samples}

Amongst the minerals studied here, some are more relevant than others in environmental geochemistry. Sphalerite isotope composition in natural samples has been extensively measured as it is the primary ore mineral (Maréchal, 1998; Maréchal et al., 1999; Mason et al., 2005; Wilkinson et al., 2005). Maréchal (1998) studied also isotopic composition of $\mathrm{Zn}$ in secondary minerals such as the carbonate minerals smithsonite and hydrozincite that could form through supergene alteration of sphalerite. Four smithsonite samples from Laurion (Greece), Wiesloch (Germany), Gabilan (Spain) and Raibl (Italy) were measured by Maréchal (1998). In these locations, smithsonite $\delta^{66} \mathrm{Zn}$ are $0.16 \%, 0.33 \%,-0.06 \%$ and $0.69 \%$ respectively, while sphalerite $\delta^{66} \mathrm{Zn}$ are $0.02 \%, 0.57 \%$, $0.00 \%$ and $0.44 \%$ respectively. Average smithsonite and sphalerite $\delta^{66} \mathrm{Zn}$ are $0.3 \pm 0.3 \%$ and $0.1 \pm 0.2 \%$ respectively. In view of these values, $\mathrm{Zn}$ isotope fractionation between the two minerals are not notably different. In the study of Maréchal (1998), one sample of hydrozincite from Riedbodeneck (Germany) is also found to be isotopically identical to a sphalerite sample from the same location. Assuming that Zn carbonates are formed by supergene alteration of sphalerite in these locations, the significant theoretical fractionation between $\mathrm{Zn}\left(\mathrm{H}_{2} \mathrm{O}\right)_{6}^{2+}$ complex and $\mathrm{Zn}$ carbonates could suggest that $\mathrm{Zn}$ is quantitatively reincorporated in precipitating secondary carbonates. The precipitation of $\mathrm{Zn}$ carbonate in low temperature environment is attested by, e.g., Jacquat et al. (2008), who have found hydrozincite in heavily $\mathrm{Zn}$ polluted carbonated soils. The study of Pašava et al. (2014) investigated zinc isotope composition in minerals at La Florida mine (Basque Cantabrian Basin, Spain), where very intense supergene alteration leads to the formation of hydrozincite, smithsonite and hemimorphite. Six sphalerite and two hydrozincite samples are measured and average $\delta^{66} \mathrm{Zn}$ values of $-0.3 \pm 0.4 \%$ and $0.3 \%$ are found respectively. In this case, the different $\delta^{66} \mathrm{Zn}$ values measured for the two minerals attests that only a fraction of $\mathrm{Zn}$ liberated by the dissolution of sphalerite has been reincorporated in secondary carbonates. The isotopic enrichment of hydrozincite is consistent with a positive theoretical fractionation factor calculated between this phase and aqueous $\mathrm{Zn}$. This is also in agreement with the experimental work of Veeramani et al. (2015). It should be noted that calculated $\beta$-factors values are for perfect minerals assuming stoichiometric $\mathrm{Zn}$ sites. In natural samples, crystalline defects, such as cationic vacancies or chemical impurities, can modify isotopic fractionation values. In addition, during supergene processes at low temperature, other phenomena such as Rayleigh or kinetic fractionation could also occur.

$\mathrm{Zn}$ isotope fractionation is also relevant to investigate high temperature geochemical processes. Terrestrial igneous rocks display an average $\delta^{66} \mathrm{Zn}$ value of $0.28 \pm$ 0.05 (Chen et al., 2013). Wang et al. (2016) suggested a possible $\mathrm{Zn}$ isotope fractionation during peridotites melting as they measured $\delta^{66} \mathrm{Zn}$ value of $0.17 \pm 0.06 \%$ in non- metasomatised peridotites, which is $\sim 0.1 \%$ lighter than primitive basalts. In peridotites, spinels are isotopically heavier than olivines and pyroxenes by $\sim 0.1 \%$. However, the two spinel minerals modelled in this study, franklinite and gahnite, display significantly different isotopic properties depending on the nature of first cation neighbours of Zn. In peridotites, spinels usually display a chemical composition with $\mathrm{Mg}, \mathrm{Fe}, \mathrm{Al}$ and $\mathrm{Cr}$ as major cations (Eggins et al., 1998) i.e., notably more complex than that of the end-members investigated in the present study. Accordingly, further studies would be required to thoroughly understand the dependence of $\mathrm{Zn}$ fractionation on the spinel chemistry to interpret the data on natural samples.

\section{Conclusion}

Equilibrium $\mathrm{Zn}$ isotope fractionation factors are calculated from first-principles in minerals covering a wide range of $\mathrm{Zn}$ crystallographic environments. Good agreement between calculated and experimental structural and vibrational properties is a guarantee of reliable theoretical isotopic fractionation factors. $\beta$-factors are calculated based either on the full-frequency or on the force constant calculations. Amongst the studied minerals, smithsonite and sphalerite display the lowest $\beta$-factors with $\ln \beta^{66} \mathrm{Zn} /{ }^{64} \mathrm{Zn}$ of $2.30 \%$ and $2.40 \%$ at $22^{\circ} \mathrm{C}$, respectively. Gahnite is the isotopically heaviest mineral with $\ln \beta^{66} \mathrm{Zn} /{ }^{64} \mathrm{Zn}$ of $4.18 \%$ at $22^{\circ} \mathrm{C}$. The range of isotopic fractionation is smaller than $2 \%$ at $22^{\circ} \mathrm{C}$, which is a consequence of small variability in $\mathrm{Zn}$ atoms first-neighbours (either $\mathrm{S}$ or $\mathrm{O}$ ) and its single oxidation state $(+2)$. Nonetheless, the closed $d$-shell of this element allows a variable coordination number $(4,5,6)$. The investigation of the theoretical isotopic fractionation shows that it is mainly driven by the Zn-first neighbour bond strength. Bond length and charge on atoms involved in the bonding affect the bond strength. The smallest bond strength and largest bond lengths are observed for octahedrally coordinated $\mathrm{Zn}$ and correspond to the smallest $\beta$-factor values and vice-versa. The equilibrium $\mathrm{Zn}$ isotope fractionation factors calculated in this study for Zn-bearing minerals along with already existing ones for solvated Zn species (Fujii et al., 2010, 2011, 2014; Black et al., 2011) provides a basis to interpret the isotopic variations observed in nature.

\section{Acknowledgements}

This work was performed using HPC resources from GENCI-IDRIS (Grant 2016-i2016041519).

This work was granted access to the HPC resources of The Institute for scientific Computing and Simulation financed by Region Ile de France and the project Equip@Meso (reference ANR-10-EQPX- 29-01) overseen by the French National Research Agency (ANR) as part of the "Investissements d'Avenir" program. 
Andersson, D. A., Stanek, C. R., 2013. Mixing and non-stoichiometry in Fe-Ni-Cr-Zn-O spinel compounds: density functional theory calculations. Phys. Chem. Chem. Phys. 15 (37), 15550-64.

Aucour, A. M., Pichat, S., MacNair, M. R., Oger, P., 2011. Fractionation of stable zinc isotopes in the zinc hyperaccumulator arabidopsis halleri and nonaccumulator arabidopsis petraea. Environ. Sci. Technol. 45 (21), 9212-9217.

Bachmann, M., Czerner, M., Edalati-Boostan, S., Heiliger, C., 2012. $\mathrm{Ab}$ initio calculations of phonon transport in $\mathrm{ZnO}$ and $\mathrm{ZnS}$. Eur. Phys. J. B 85 (5).

Balan, E., Blanchard, M., Pinilla, C., Lazzeri, M., 2014. Firstprinciples modeling of sulfate incorporation and ${ }^{34} \mathrm{~S} /{ }^{32} \mathrm{~S}$ isotopic fractionation in different calcium carbonates. Chem. Geol. 374-375, 84-91.

Balassone, G., Rossi, M., Boni, M., Stanley, G., McDermott, P., 2008. Mineralogical and geochemical characterization of nonsulfide $\mathrm{Zn}-\mathrm{Pb}$ mineralization at Silvermines and Galmoy (Irish Midlands). Ore Geol. Rev. 33 (2), 168-186.

Balistrieri, L. S., Borrok, D. M., Wanty, R. B., Ridley, W. I., 2008. Fractionation of $\mathrm{Cu}$ and $\mathrm{Zn}$ isotopes during adsorption onto amorphous Fe(III) oxyhydroxide: Experimental mixing of acid rock drainage and ambient river water. Geochim. et Cosmochim. Acta $72(2), 311-328$.

Ball, J. W., Nordstrom, K. D., 1991. User's manual for WATEQ4F, with revised thermodynamic data base and test cases for calculating speciation of major trace, and redox elements in natural waters 91-183.

Bigeleisen, J., Mayer, M. G., 1947. Calculation of Equilibrium Constants for Isotopic Exchange Reactions. J. Chem. Phys. 15 (5), $261-267$.

Black, J. R., Kavner, A., Schauble, E. A., 2011. Calculation of equilibrium stable isotope partition function ratios for aqueous zinc complexes and metallic zinc. Geochim. Cosmochim. Acta 75 (3), 769-783.

Blanchard, M., Balan, E., Schauble, E., 2017 in press. Equilibrium Fractionation of Non-Traditional Isotopes: a Molecular Modeling Perspective. Rev. Mineral. Geochem. 82 (x), xx - xx.

Blanchard, M., Morin, G., Lazzeri, M., Balan, E., 2010. Firstprinciples study of the structural and isotopic properties of $\mathrm{Al}$ and $\mathrm{OH}$-bearing hematite. Geochim. Cosmochim. Acta 74 (14), 3948-3962

Blanchard, M., Poitrasson, F., Méheut, M., Lazzeri, M., Mauri, F. Balan, E., 2009. Iron isotope fractionation between pyrite (FeS2), hematite (Fe2O3) and siderite (FeCO3): A first-principles density functional theory study. Geochim. Cosmochim. Acta 73 (21), $6565-6578$

Boni, M., Coppola, V., Deionghe, L., Fedele, L., 2005. Willemite in the Belgian non-sulfide zinc deposits: A fluid inclusion study. Period. Mineral. 74 (1), 87-100.

Borrok, D. M., Nimick, D. a., Wanty, R. B., Ridley, W. I., 2008. Isotopic variations of dissolved copper and zinc in stream waters affected by historical mining. Geochim. Cosmochim. Acta 72 (2), $329-344$.

Borrok, D. M., Wanty, R. B., Ian Ridley, W., Lamothe, P. J., Kimball, B. A., Verplanck, P. L., Runkel, R. L., 2009. Application of iron and zinc isotopes to track the sources and mechanisms of metal loading in a mountain watershed. Appl. Geochem. 24 (7), 1270-1277.

Bouibes, A., Zaoui, A., Tunega, D., 2013. Bonds, bands and elasticity of smithsonite rock. Solid State Commun. 166, 76-82.

Braestrup, F., Hauback, B. C., Hansen, K. K., Bræstrup, F., 2008. Temperature dependence of the cation distribution in $\mathrm{ZnFe}_{2} \mathrm{O}_{4}$ measured with high temperature neutron diffraction. J. Solid State Chem. 181 (9), 2364-2369

Brafman, O., Mitra, S. S., 1968. Raman effect in wurtzite- and zincblende-type ZnS single crystals. Phys. Rev. 171 (3), 931-934.

Bryan, A. L., Dong, S., Wilkes, E. B., Wasylenki, L. E., 2015. Zinc isotope fractionation during adsorption onto Mn oxyhydroxide at low and high ionic strength. Geochim. Cosmochim. Acta 157 (2015), 182-197.

Chao, G. Y., Gault, R. A., 1998. The occurrence of two rare poly- types of wurtzite, $4 \mathrm{H}$ and $8 \mathrm{H}$, at mont Saint-Hilaire, Quebec. Can. Mineral. 36 (3), 775-778.

Chen, H., Savage, P. S., Teng, F. Z., Helz, R. T., Moynier, F., 2013. Zinc isotope fractionation during magmatic differentiation and the isotopic composition of the bulk Earth. Earth Planet. Sci. Lett. 369-370, 34-42.

Chen, J., Gaillardet, J., Louvat, P., Huon, S., 2009. Zn isotopes in the suspended load of the Seine River, France: Isotopic variations and source determination. Geochim. Cosmochim. Acta 73 (14), 4060-4076.

Cheng, C., 2008. Long-range antiferromagnetic interactions in $\mathrm{ZnFe}_{2} \mathrm{O}_{4}$ and $\mathrm{CdFe}_{2} \mathrm{O}_{4}$ : Density functional theory calculations. Phys. Rev. B 78 (13), 2-5.

Chopelas, A., Hofmeister, A., 1991. Vibrational Spectroscopy of Aluminate Spinels at 1 atm and of $\mathrm{MgAl}_{2} \mathrm{O}_{4}$ to Over 200 kbar. Phys. Chem. Miner. 18, 279-293.

Cloquet, C., Carignan, J., Libourel, G., 2006. Isotopic Composition of $\mathrm{Zn}$ and $\mathrm{Pb}$ Atmospheric Depositions in an Urban/Periurban Area of Northeastern France. Environ. Sci. Technol. 40 (21), 65946600 .

Damen, T., Porto, S., Tell, B., Review, Y., 1966. Raman Effect in Zinc Oxide. Phys. Rev. 142 (2), 570-574.

Eggins, S., Rudnick, R., McDonough, W., 1998. The composition of peridotites and their minerals: a laser-ablation ICPMS study. Earth and Planetary Science Letters 154 (February 1997), 53-71.

Favot, F., Dal Corso, A., 1999. Phonon dispersions: Performance of the generalized gradient approximation. Phys. Rev. B 60 (16), $427-431$.

Frassinetti, S., Bronzetti, G. L., Caltavuturo, L., Cini, M., Della Croce, C., 2006. The role of zinc in life: A review. Journal of Environmental Pathology, Toxicology and Oncology 25 (3), 597-610.

Frost, R. L., Hales, M. C., Wain, D. L., 2008a. Raman spectroscopy of smithsonite. J. Raman Spectrosc 39, 108-114.

Frost, R. L., Martens, W. N., Wain, D. L., Hales, M. C., 2008 b. Infrared and infrared emission spectroscopy of the zinc carbonate mineral smithsonite. Spectrochim. Acta Part A: Mol. Biomol. Spectrosc. 70 (5), 1120-1126.

Fujii, T., Albarède, F., 2012. Ab initio calculation of the Zn isotope effect in phosphates, citrates, and malates and applications to plants and soil. PLoS ONE 7 (2), 0-4.

Fujii, T., Moynier, F., Blichert-Toft, J., Albarède, F., 2014. Density functional theory estimation of isotope fractionation of $\mathrm{Fe}, \mathrm{Ni}$, $\mathrm{Cu}$, and $\mathrm{Zn}$ among species relevant to geochemical and biological environments. Geochim. Cosmochim. Acta 140 (2014), 553-576.

Fujii, T., Moynier, F., Pons, M. L., Albarède, F., 2011. The origin of $\mathrm{Zn}$ isotope fractionation in sulfides. Geochim. Cosmochim. Acta 75 (23), 7632-7643.

Fujii, T., Moynier, F., Telouk, P., Abe, M., 2010. Experimental and theoretical investigation of isotope fractionation of zinc between aqua, chloro, and macrocyclic complexes. J. Phys. Chem. A 114 (7), 2543-2552.

Gagnevin, D., Boyce, a. J., Barrie, C. D., Menuge, J. F., Blakeman, R. J., 2012. Zn, Fe and S isotope fractionation in a large hydrothermal system. Geochim. Cosmochim. Acta 88, 183-198.

Garrity, K., Bennett, J., Rabe, K., Vanderbilt, D., 2014. Pseudopotentials for high-throughput DFT calculations. Comput. Mater. Sci. 81, 446-452.

Gélabert, A., Pokrovsky, O. S., Viers, J., Schott, J., Boudou, A., Feurtet-Mazel, A., 2006. Interaction between zinc and freshwater and marine diatom species: Surface complexation and $\mathrm{Zn}$ isotope fractionation. Geochim. Cosmochim. Acta 70 (4), 839-857.

Ghose, S., 1964. The crystal structure of hydrozincite, $\mathrm{Zn}_{5}(\mathrm{OH})_{6}\left(\mathrm{CO}_{3}\right)_{2}$. Acta Crystallogr. 17 (8), 1051-1057.

Giannozzi, P., Baroni, S., Bonini, N., Calandra, M., Car, R., Cavazzoni, C., Ceresoli, D., Chiarotti, G. L., Cococcioni, M., Dabo, I., Dal Corso, A., de Gironcoli, S., Fabris, S., Fratesi, G., Gebauer, R., Gerstmann, U., Gougoussis, C., Kokalj, A., Lazzeri, M., Martin-Samos, L., Marzari, N., Mauri, F., Mazzarello, R., Paolini, S., Pasquarello, A., Paulatto, L., Sbraccia, C., Scandolo, S., Sclauzero, G., Seitsonen, A. P., Smogunov, A., Umari, P., Wentz- 
covitch, R. M., 2009. QUANTUM ESPRESSO: a modular and open-source software project for quantum simulations of materials. J. Phys. Condens. Matter 21, 395502.

Graf, D. L., 1961. Crystallographic tables for the rhombohedral carbonates. Am. Mineral. 46, 1283-1316.

Guinoiseau, D., Gélabert, A., Moureau, J., Louvat, P., Benedetti, M. F., 2016. Zn Isotope Fractionation during Sorption onto Kaolinite. Environ. Sci. Technol., acs.est.5b05347.

Hales, M. C., Frost, R. L., 2007. Synthesis and vibrational spectroscopic characterisation of synthetic hydrozincite and smithsonite. Polyhedron 26 (17), 4955-4962.

He, L., Liu, F., Hautier, G., Oliveira, M. J. T., Marques, M. A. L., Vila, F. D., Rehr, J. J., Rignanese, G. M., Zhou, A., 2014. Accuracy of generalized gradient approximation functionals for densityfunctional perturbation theory calculations. Phys. Rev. B 89 (6), $1-15$.

Herzog, G. F., Moynier, F., Albarède, F., Berezhnoy, A. A., 2009. Isotopic and elemental abundances of copper and zinc in lunar samples, Zagami, Pele's hairs, and a terrestrial basalt. Geochim. Cosmochim. Acta 73 (19), 5884-5904.

Hill, R. J., 1976. The crystal structure and infrared properties of adamite 61 (9-10), 979-986.

Hochella, M. F., Moore, J. N., Golla, U., Putnis, A., 1999. A TEM study of samples from acid mine drainage systems: Metal-mineral association with implications for transport. Geochim. Cosmochim. Acta 63 (19-20), 3395-3406.

Jacquat, O., Voegelin, A., Kretzschmar, R., 2009. Soil properties controlling Zn speciation and fractionation in contaminated soils. Geochim. Cosmochim. Acta 73 (18), 5256-5272.

Jacquat, O., Voegelin, A., Villard, A., Marcus, M. a., Kretzschmar, R., 2008. Formation of Zn-rich phyllosilicate, Zn-layered double hydroxide and hydrozincite in contaminated calcareous soils. Geochim. Cosmochim. Acta 72, 5037-5054.

Jambor, J. L., Boyle, R. W., 1962. Gunningite, a new zinc sulphate from the Keno Hill-Galena HIll area, Yukon. Can. Mineral. 7, 209-218.

John, S. G., Geis, R. W., Saito, M. a., Boyle, E. A., 2007. Zinc isotope fractionation during high-affinity and low-affinity zinc transport by the marine diatom Thalassiosira oceanica. Limnol. Oceanogr. 52 (6), 2710-2714.

Juillot, F., Maréchal, C., Morin, G., Jouvin, D., Cacaly, S., Telouk, P., Benedetti, M. F., Ildefonse, P., Sutton, S., Guyot, F., Brown, G. E., 2011. Contrasting isotopic signatures between anthropogenic and geogenic $\mathrm{Zn}$ and evidence for post-depositional fractionation processes in smelter-impacted soils from Northern France. Geochim. Cosmochim. Acta 75 (9), 2295-2308.

Juillot, F., Maréchal, C., Ponthieu, M., Cacaly, S., Morin, G., Benedetti, M., Hazemann, J. L., Proux, O., Guyot, F., 2008. Zn isotopic fractionation caused by sorption on goethite and 2-Lines ferrihydrite. Geochim. Cosmochim. Acta 72 (19), 4886-4900

Juillot, F., Morin, G., Ildefonse, P., Trainor, T. P., Benedetti, M., Galoisy, L., Calas, G., Brown, G. E., 2003. Occurrence of Zn/Al hydrotalcite in smelter-impacted soils from northern France: Evidence from EXAFS spectroscopy and chemical extractions. Am. Mineral. 88 (4), 509-526.

Kato, C., Moynier, F., Valdes, M. C., Dhaliwal, J. K., Day, J. M. D., 2015. Extensive volatile loss during formation and differentiation of the Moon. Nature communications 6 (May), 7617.

Kisi, E. H., Elcombe, M. M., 1989. u parameters for the wurtzite structure of $\mathrm{ZnS}$ and $\mathrm{ZnO}$ using powder neutron diffraction. Acta Crystallogr. C 45 (12), 1867-1870.

Kowalski, P. M., Jahn, S., 2011. Prediction of equilibrium Li isotope fractionation between minerals and aqueous solutions at high $\mathrm{P}$ and T: An efficient ab initio approach. Geochim. Cosmochim. Acta 75 (20), 6112-6123.

Kowalski, P. M., Wunder, B., Jahn, S., 2013. Ab initio prediction of equilibrium boron isotope fractionation between minerals and aqueous fluids at high $\mathrm{P}$ and T. Geochim. Cosmochim. Acta 101 (2013), 285-301.

Kucha, H., Martens, a., Ottenburgs, R., DeVos, W., Viaene, W., 1996. Primary minerals of $\mathrm{Zn}-\mathrm{Pb}$ mining and metallurgical dumps and their environmental behavior at Plombieres, Belgium. Environ. Geol. 27 (1), 1-15.

Libowitzky, E., Rossman, G. R., 1997. IR spectroscopy of hemimorphite between 82 and $373 \mathrm{~K}$ and optical evidence for a lowtemperature phase transition. Europ. J. Mineral. 9 (4), 793-802.

Little, S. H., Vance, D., Walker-Brown, C., Landing, W. M., 2014. The oceanic mass balance of copper and zinc isotopes, investigated by analysis of their inputs, and outputs to ferromanganese oxide sediments. Geochim. Cosmochim. Acta 125 (2014), 673-693.

Macris, C. A., Manning, C. E., Young, E. D., 2015. Crystal chemical constraints on inter-mineral Fe isotope fractionation and implications for Fe isotope disequilibrium in San Carlos mantle xenoliths. Geochim. Cosmochim. Acta 154, 168-185.

Maréchal, C., 1998. Géochimie des isotopes du cuivre et du zinc : Méthode, variabilité naturelle et application océanographique. Ph.D. thesis, Université Joseph Fourier - Grenoble 1.

Maréchal, C. N., Télouk, P., Albarède, F., 1999. Precise analysis of copper and zinc isotopic compositions by plasma-source mass spectrometry. Chem. Geol. 156 (1-4), 251-273.

Martyna, G. J., Tuckerman, M. E., 1999. A reciprocal space based method for treating long range interactions in ab initio and forcefield-based calculations in clusters. J. Chem. Phys. 110 (6), 2810.

Mason, T. F. D., Weiss, D. J., Chapman, J. B., Wilkinson, J. J., Tessalina, S. G., Spiro, B., Horstwood, M. S. A., Spratt, J., Coles, B. J., 2005. $\mathrm{Zn}$ and $\mathrm{Cu}$ isotopic variability in the Alexandrinka volcanic-hosted massive sulphide (VHMS) ore deposit, Urals, Russia. Chem. Geol. 221 (3-4), 170-187.

Mattielli, N., Petit, J. C. J., Deboudt, K., Flament, P., Perdrix, E., Taillez, A., Rimetz-Planchon, J., Weis, D., 2009. Zn isotope study of atmospheric emissions and dry depositions within a $5 \mathrm{~km}$ radius of a $\mathrm{Pb}-\mathrm{Zn}$ refinery. Atmosp. Environ. 43 (6), 1265-1272.

Méheut, M., Lazzeri, M., Balan, E., Mauri, F., 2007. Equilibrium isotopic fractionation in the kaolinite, quartz, water system: Prediction from first-principles density-functional theory. Geochim. Cosmochim. Acta 71 (13), 3170-3181.

Méheut, M., Lazzeri, M., Balan, E., Mauri, F., 2009. Structural control over equilibrium silicon and oxygen isotopic fractionation: A first-principles density-functional theory study. Chem. Geol. 258 (1-2), 28-37.

Méheut, M., Schauble, E. a., 2014. Silicon isotope fractionation in silicate minerals: Insights from first-principles models of phyllosilicates, albite and pyrope. Geochim. Cosmochim. Acta 134, 137154

Mitchell, D. W., Das, T. P., Potzel, W., Schiessl, W., Karzel, H., Steiner, M., Köfferlein, M., Hiller, U., Kalvius, G. M., Martin, A., Schäfer, W., Will, G., Halevy, I., Gal, J., 1996. Ab initio electricfield gradients and electron densities at ${ }^{27} \mathrm{Al},{ }^{57} \mathrm{Fe}$, and ${ }^{67} \mathrm{Zn}$ in the spinels $\mathrm{ZnAl}_{2} \mathrm{O}_{4}$ and $\mathrm{ZnFe}_{2} \mathrm{O}_{4}$. Phys. Rev. B 53, 7684-7698.

Monkhorst, H., Pack, J., 1976. Special points for Brillouin-zone integrations. Phys. Rev. B 13, 1227-1230.

Moynier, F., Beck, P., Jourdan, F., Yin, Q. Z., Reimold, U., Koeberl, C., 2009a. Isotopic fractionation of zinc in tektites. Earth Planet. Sci. Lett. 277 (3-4), 482-489.

Moynier, F., Paniello, R. C., Gounelle, M., Albarède, F., Beck, P., Podosek, F., Zanda, B., 2011a. Nature of volatile depletion and genetic relationships in enstatite chondrites and aubrites inferred from $\mathrm{Zn}$ isotopes. Geochim. Cosmochim. Acta 75 (1), 297-307.

Moynier, F., Pichat, S., Pons, M. L., Fike, D., Balter, V., Albarède, F., 2009b. Isotopic fractionation and transport mechanisms of $\mathrm{Zn}$ in plants. Chem. Geol. 267 (3-4), 125-130.

Moynier, F., Yin, Q.-Z., Schauble, E., 2011b. Isotopic evidence of Cr partitioning into Earth's core. Sci. 331 (6023), 1417-1420.

Paniello, R. C., Day, J. M. D., Moynier, F., 2012. Zinc isotopic evidence for the origin of the Moon. Nat. 490 (7420), 376-379.

Parkhurst, D. L., Appelo, C. A. J., 1999. User's guide to PHREEQC (Version 2) : a computer program for speciation, batch-reaction, one-dimensional transport, and inverse geochemical calculations. Water-Resour. Investig. Rep. 99-4259.

Pašava, J., Tornos, F., Chrastný, V., 2014. Zinc and sulfur isotope variation in sphalerite from carbonate-hosted zinc deposits, Cantabria, Spain. Miner. Depos. 49, 797-807. 
Perdew, J. P., Burke, K., Ernzerhof, M., 1996. Generalized Gradient Approximation Made Simple. Phys. Rev. Lett. 77, 3865-3868.

Pichat, S., Douchet, C., Albarède, F., 2003. Zinc isotope variations in deep-sea carbonates from the eastern equatorial Pacific over the last 175 ka. Earth Planet. Sci. Lett. 210 (1-2), 167-178.

Pokrovsky, O. S., Viers, J., Freydier, R., 2005. Zinc stable isotope fractionation during its adsorption on oxides and hydroxides. J. Colloid and Interface Sci. 291 (1), 192-200.

Pons, M.-L., Quitte, G., Fujii, T., Rosing, M. T., Reynard, B., Moynier, F., Douchet, C., Albarede, F., 2011. Early Archean serpentine mud volcanoes at Isua, Greenland, as a niche for early life. Proc. Natl. Acad. Sci. 108 (43), 17639-17643.

Rauch, J. N., Pacyna, J. M., 2009. Earth's global Ag, Al, Cr, Cu, $\mathrm{Fe}, \mathrm{Ni}, \mathrm{Pb}$, and $\mathrm{Zn}$ cycles. Glob. Biogeochem. Cycles 23 (2), 1-16.

Rudolph, W. W., Brooker, M. H., Tremaine, P. R., 1999. Raman Spectroscopy of Aqueous ZnSO4 Solutions under Hydrothermal Conditions: Solubility, Hydrolysis, and Sulfate Ion Pairing. J. Solut. Chem. 28 (5), 621-630.

Schauble, E., 2004. Applying stable isotope fractionation theory to new systems. Rev. Mineral. Geochem. 55 (1), 65.

Schauble, E. A., 2003. Modeling zinc isotope fractionations, Am. Geophys. Union, Fall Meeting 2003, abstract\#B12B-0781.

Schauble, E. A., 2011. First-principles estimates of equilibrium magnesium isotope fractionation in silicate, oxide, carbonate and hexaaquamagnesium $(2+)$ crystals. Geochim. Cosmochim. Acta 75 (3), 844-869.

Schauble, E. A., Ghosh, P., Eiler, J. M., 2006. Preferential formation of $13 \mathrm{C} 18 \mathrm{O}$ bonds in carbonate minerals, estimated using first-principles lattice dynamics. Geochim. Cosmochim. Acta 70, 2510-2529.

Skinner, B. J., 1961. Unit-cell edges of natural and synthetic sphalerites 46, 1399-1411.

Sobanska, S., 1999. Etude de la spéciation du plomb et du zinc dans des poussières industrielles et dans un sol contaminé. Ph.D. thesis, Université des Sciences et Technologies de Lille.

Steger, H. F., Desjardins, L. E., 1980. Oxidation of sulfide minerals. V. Galena, sphalerite and chalcocite. Can. Mineral. 18 (1980), 365-372.

Toutain, J. P., Sonke, J., Munoz, M., Nonell, A., Polvé, M., Viers, J., Freydier, R., Sortino, F., Joron, J. L., Sumarti, S., 2008. Evidence for $\mathrm{Zn}$ isotopic fractionation at Merapi volcano. Chem. Geol. $253(1-2), 74-82$.

Urey, H. C., 1947. The thermodynamic properties of isotopic substances. J. Chem. Soc. (Resumed), 562

Veeramani, H., Eagling, J., Jamieson-Hanes, J. H., Kong, L., Ptacek, C. J., Blowes, D. W., 2015. Zinc isotope fractionation as an indicator of geochemical attenuation processes. Environ. Sci. Technol. Lett. 2 (11), 314-319.

Viers, J., Oliva, P., Nonell, A., Gélabert, A., Sonke, J. E., Freydier, R., Gainville, R., Dupré, B., 2007. Evidence of Zn isotopic fractionation in a soil-plant system of a pristine tropical watershed (Nsimi, Cameroon). Chem. Geol. 239 (1-2), 124-137.

Wang, Z. Z., Liu, S. A., Liu, J., Huang, J., Xiao, Y., 2016. Zinc isotope fractionation during partial melting of the Earth's upper mantle, goldschmidt Conference Abstracts, 3361.

Weiss, D. J., Mason, T. F. D., Zhao, F. J., Kirk, G. J. D., Coles, B. J., Horstwood, M. S. A., 2005. Isotopic discrimination of zinc in higher plants. New Phytol. 165 (3), 703-710.

Weiss, D. J., Rausch, N., Mason, T. F. D., Coles, B. J., Wilkinson, J. J., Ukonmaanaho, L., Arnold, T., Nieminen, T. M., 2007. Atmospheric deposition and isotope bioGeochem. of zinc in ombrotrophic peat. Geochim. Cosmochim. Acta 71 (14), 3498-3517.

Widanagamage, I. H., Schauble, E. A., Scher, H. D., Griffith, E. M., 2014. Stable strontium isotope fractionation in synthetic barite. Geochim. Cosmochim. Acta 147, 58-75.

Wildner, M., Giester, G., 1991. The crystal structures of kieserite-type compounds. I, Crystal structures of $\mathrm{Me}(\mathrm{II}) \mathrm{SO}_{4} \cdot \mathrm{H}_{2} \mathrm{O}$ $(\mathrm{Me}=\mathrm{Mn}, \mathrm{Fe}, \mathrm{Co}, \mathrm{Ni}, \mathrm{Zn})$. Neues Jahrb. Mineral. Monat. (7), 296306.

Wilkinson, J. J., Weiss, D. J., Mason, T. F. D., Coles, B. J., 2005. Zinc isotope variation in hydrothermal systems: Preliminary evi- dence from the irish midlands ore field. Econ. Geol. 100 (3), 583590

Yin, N. H., Sivry, Y., Benedetti, M. F., Lens, P. N. L., van Hullebusch, E. D., 2015. Application of $\mathrm{Zn}$ isotopes in environmental impact assessment of $\mathrm{Zn}-\mathrm{Pb}$ metallurgical industries: A mini review. Appl. Geochem. 64 (2016), 128-135.

Young, E. D., Manning, C. E., Schauble, E. a., Shahar, A., Macris, C. a., Lazar, C., Jordan, M., 2015. High-temperature equilibrium isotope fractionation of non-traditional stable isotopes: Experiments, theory, and applications. Chem. Geol. 395 (2015), 176-195.

Young, E. D., Tonui, E., Manning, C. E., Schauble, E., Macris, C. a., 2009. Spinel-olivine magnesium isotope thermometry in the mantle and implications for the $\mathrm{Mg}$ isotopic composition of Earth. Earth Planet. Sci. Lett. 288 (3-4), 524-533.

Yousaf, M., Saeed, M. A., Isa, A. R. M., Aliabad, H. A. R., Noor, N. A., 2012. Ab initio study of optoelectronic properties of spinel $\mathrm{ZnAl}_{2} \mathrm{O}_{4}$ beyond GGA and LDA. Int. J. Mod. Phys. B 26 (32), $1-13$.

Zhao, Y., Vance, D., Abouchami, W., de Baar, H. J. W., 2014. Biogeochemical cycling of zinc and its isotopes in the Southern Ocean. Geochim. Cosmochim. Acta 125, 653-672. 